\title{
IMPACT OF GROUND WATER SALINITY AND SODICITY ON SOIL CHEMICAL PROPERTIES AT SOILS NEARBY QAROUN LAKE, FAYOUM, EGYPT.
}

\author{
Hala Hussein R.; Mohamed, H. A. El-Shakweer; Mohamed, S.A. Ewees
}

and Abdel-Nasser, A. A. Abdel-Hafeez

Soil and Water Dep, Faculty of Agriculture, Fayoum University, Egypt

\begin{abstract}
To study the effect of ground water salinity and sodicity on some soil chemical properties, the selected area under study comprised the nearest northern fringes of Qaroun lake shoreline, which considered as the main outlet of drainage water of El Fayoum Governorate via many drainage canals. The parent materials of most lands are more related to calcareous coarse textured nature. These soils were put under reclamation in sequence more than ten years ago, and most of their lands were put under cultivation. The newly cultivation, surface irrigation and the insufficient drainage system make up water ground table raised. In general, soil chemical properties showed that most of the soil profiles under investigation suffer from salinity appearances. Therefore, it is accepted that such soils might need to reclamation and amelioration processes. The relationships between different soil variables and ground water characteristics reflect highly positive correlation between soil salinity and ground water salinity, whereas, the reverse was observed with ground water depth, which showed a negative and highly significant correlation.

In order to permanently improve the studied soil area, it is necessary to not only leach salts, but also to have adequate drainage .The drainage system must provide a lot amounts let for the removal of the leachates as well as keep the water table deep enough to prevent salt ground water from moving up to the root zone. Gypsum must be added according to gypsum requirements.

Key words: Shallow water table - Soil salinity - Soil sodicity-Soil chemical properties - Qaroun Lake INTRODUCTION
\end{abstract}

Salinity problems caused by the presence of saline ground water at shallow depths are widely acknowledged to adversely affect production from the world's irrigated land, especially in arid and semi-arid regions, Elrick et al. (1994). Extensive areas of land in Egypt, particular, Fayoum area have been gone out of cultivation due to the rise of ground water and consequently accumulation of salts; meanwhile poor water management, excessive irrigation water, seepage from irrigation canals and inadequate drainage which considered as the main reasons of ground water table rise, water logging and active salt build-up Hassan et al., (1999). Saeed et al., (2011) found that under the same atmospheric demand, evaporation from the soil surface was

Fayoum J. Agric. Res. \& Dev., Vol. 31, No.1, January, 2017 
significantly affected by the depth of the water table which increased soil ECe. A shallow water table in combination with high soil salinity often leads to permanent soil resources degradation. In arid and semi-arid climates, soil salinization constitutes a major problem for irrigated land sustainability, throughout the world, about $25 \%$ of irrigated area are affected by salinity and waterlogging, Rhoads et al. (1992). Shallow ground water influences 22 to $32 \%$ of global land area, including $-15 \%$ as ground water-fed surface water features and 7 to $17 \%$ with the water table or its capillary fringe within plant rooting depths (Fan, et al. 2013). A saline shallow water table can contribute significantly to salinity/sodicity development in the root zone, Ashraf et. al. (2006). Ali et. al. (2000) reported that under shallow water table conditions, ground water may be a significant source of salts in the development of salt affected soils.

\section{Materials and Methods}

The area under study comprised the nearest north-eastern fringes of Qaroun lake shoreline, which considered as the main outlet of drainage water of El Fayoum Governorate via many drainage canals. Eighteen soil profiles were selected representing, the new reclaimed soils north-eastern of Qaroun Lake (El-Fayoum Governorate, Egypt), in three sample areas Fig (1). The first includes 7 soil profiles in vertical direction with the lake shoreline (profiles no. 1, 2, 3, 4, 5, 6 and 7), the second sample area includes 5 soil profiles scattered nearby and parallel to lake shoreline (profiles no. 8, 9, 10, 11 and 12), the third sample area conducted in slope way between the two other sample areas and presented by six soil profiles $(13,14,15,16,17$ and 18). The eighteen soil profiles were dug to $120 \mathrm{~cm}$ or water table level. The particle size distribution and texture classes of the studied soil profiles were represented in Table (1).

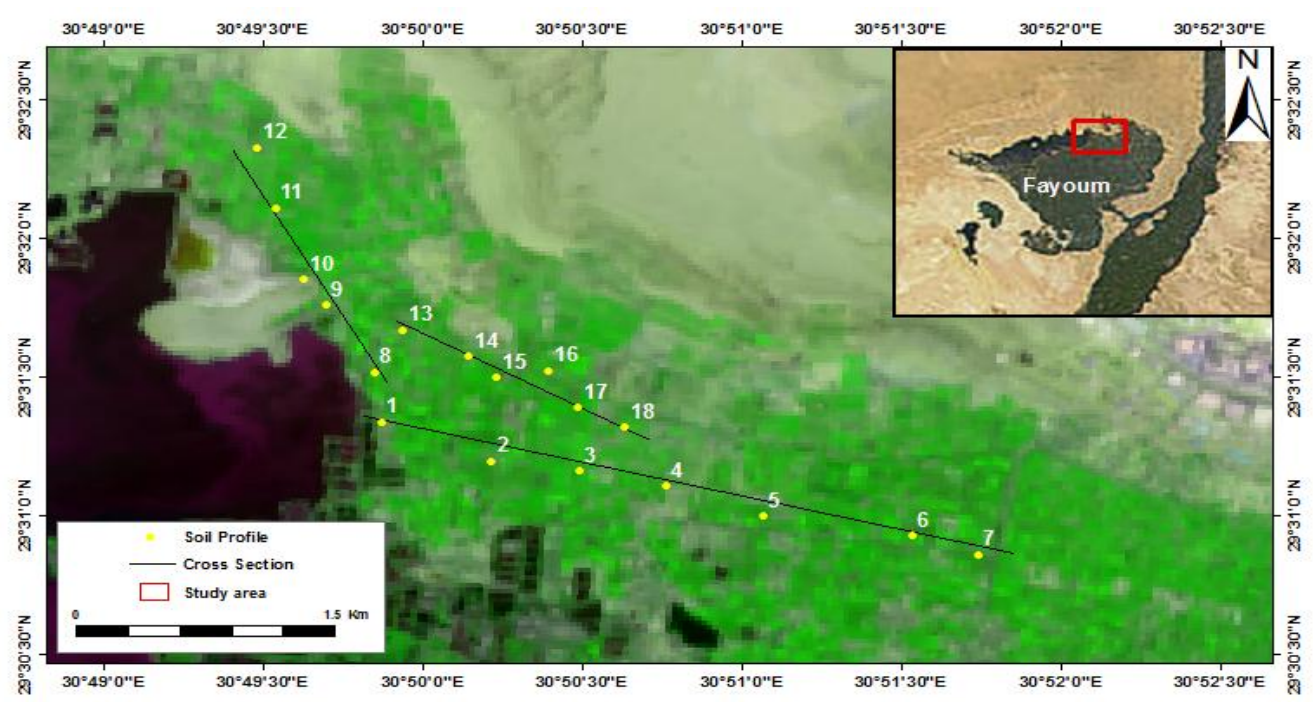

Figure 1: Location map of the studied area and soil profiles.

Fayoum J. Agric. Res. \& Dev., Vol. 31, No.1, January, 2017 
IMPACT OF GROUND WATER SALINITY AND SODICITY.

Table (1):Particle size distribution and texture classes of the studied soil samples.

\begin{tabular}{|c|c|c|c|c|c|}
\hline \multirow{2}{*}{$\begin{array}{c}\text { Pr } \\
\text { No. }\end{array}$} & \multirow{2}{*}{ Depth (cm) } & \multicolumn{3}{|c|}{ Particle size distribution (\%) } & \multirow{2}{*}{ Texture class } \\
\hline & & Sand $\%$ & Silt\% & Clay\% & \\
\hline \multirow{2}{*}{1} & $0-20$ & 76.7 & 5.9 & 17.4 & Sandy loam \\
\hline & $20-40$ & 89.1 & 5.5 & 5.4 & Sandy \\
\hline \multirow{2}{*}{2} & $0-30$ & 46.6 & 11.6 & 41.8 & Sandy clay \\
\hline & $30-60$ & 50.1 & 30.8 & 19.1 & Loam \\
\hline \multirow{2}{*}{3} & $0-30$ & 51.2 & 8.7 & 40.1 & Sandy clay \\
\hline & $30-70$ & 74.9 & 5.3 & 19.8 & Sandy loam \\
\hline \multirow{2}{*}{4} & $0-30$ & 26.5 & 12.3 & 61.2 & Clay \\
\hline & $30-60$ & 29.1 & 12.5 & 58.4 & Clay \\
\hline \multirow{2}{*}{5} & $0-30$ & 33.1 & 6.2 & 60.7 & Clay \\
\hline & $30-55$ & 33.1 & 39.3 & 27.6 & Clay loam \\
\hline \multirow{2}{*}{6} & $0-40$ & 29.5 & 30.7 & 39.8 & Sandy clay \\
\hline & $40-80$ & 74.4 & 6.7 & 18.9 & Sandy loam \\
\hline \multirow{2}{*}{7} & $0-30$ & 36.6 & 12.3 & 51.1 & Clay \\
\hline & $30-70$ & 84.9 & 5.4 & 9.7 & Loamy sand \\
\hline \multirow{3}{*}{8} & $0-20$ & 46.9 & 5.3 & 47.8 & Clay \\
\hline & $20-45$ & 77.1 & 5.1 & 17.8 & Sandy loam \\
\hline & $45-75$ & 75.4 & 7.4 & 17.2 & Sandy loam \\
\hline \multirow{2}{*}{9} & $0-30$ & 35.6 & 12.1 & 52.3 & Clay \\
\hline & $30-60$ & 48.7 & 33.2 & 18.1 & Loam \\
\hline \multirow{2}{*}{10} & $0-30$ & 74.7 & 6.1 & 19.2 & Sandy loam \\
\hline & $30-60$ & 79.3 & 15.6 & 5.1 & Loamy sand \\
\hline \multirow{2}{*}{11} & $0-30$ & 37.8 & 29.3 & 32.9 & Clav loam \\
\hline & $30-60$ & 75.7 & 6.2 & 18.1 & Sandy loam \\
\hline \multirow{4}{*}{12} & $0-30$ & 75.1 & 6.6 & 18.3 & Sandy loam \\
\hline & $30-70$ & 88.4 & 5.9 & 5.7 & Sandy \\
\hline & $70-100$ & 88.3 & 6.1 & 5.6 & Sandv \\
\hline & $100-120$ & 83.1 & 5.8 & 11.1 & Loamy sand \\
\hline \multirow[t]{2}{*}{13} & $0-40$ & 71.3 & 9.1 & 19.6 & Sandy loam \\
\hline & $40-80$ & 74.6 & 7.6 & 17.8 & Sandy loam \\
\hline \multirow{2}{*}{14} & $0-20$ & 73.7 & 7.6 & 18.7 & Sandy loam \\
\hline & $20-70$ & 76.7 & 16.8 & 6.5 & Loamy sand \\
\hline \multirow{2}{*}{15} & $0-40$ & 46.1 & 7.1 & 46.8 & Sandy clay \\
\hline & $40-100$ & 77.1 & 16.5 & 6.4 & Loamy sand \\
\hline \multirow{2}{*}{16} & $0-30$ & 48.6 & 5.7 & 45.7 & Sandv clav \\
\hline & $30-80$ & 73.9 & 7.3 & 18.8 & Sandy loam \\
\hline \multirow{2}{*}{17} & $0-30$ & 30.3 & 41.4 & 28.3 & Clay loam \\
\hline & $30-100$ & 32.1 & 38.7 & 24.2 & Loam \\
\hline \multirow{2}{*}{18} & $0-40$ & 32.5 & 12.1 & 55.4 & Clay \\
\hline & $40-80$ & 71.3 & 9.1 & 19.6 & Sandy loam \\
\hline
\end{tabular}

Fayoum J. Agric. Res. \& Dev., Vol. 31, No.1, January, 2017 
Hala Hussein R. et al.,

Soil and ground water analysis

The disturbed and undisturbed soil samples were collected to determine the soil properties. Soil chemical properties and chemical determinations of ground water samples $\left(\mathrm{pH}, \mathrm{ECe}, \mathrm{ECw}, \mathrm{CaCO}_{3}, \mathrm{OM}\right.$, soluble cations, soluble anions, $\mathrm{CEC}$, exchangeable $\mathrm{Na}$ ) were conducted according to Page et al. (1982). Nitrate $\left(\mathbf{N O}_{3}\right)$ was determined using uvspectrophotometer according to (method 4500- $\left.\mathrm{NO}_{3}^{-} \mathrm{B}\right)$ APHA- AWWA and WEF (2005). The percent sodium $\left(\mathrm{Na}^{+} \%\right)$ was calculated according to Wicox (1995) as follows:

$$
\mathrm{Na} \%=\frac{\mathrm{Na}^{+}}{\mathrm{Ca}^{+2}+\mathrm{Mg}^{+2}+\mathrm{Na}^{+}+\mathrm{K}^{+}} \%
$$

Some soil physical properties were conducted to Klute (1986) Table (1). Statistical relationships between ground water characteristics and some soil properties (soil variables) were statistically analyzed by using the program outlined by SPSS Software to distinguish the possible statistical and mathematical relationships between the tested ground water characteristics and soil properties.

\section{Results and Discussions}

Chemistry of ground water

Chemistry of ground water plays an important role in soil salinity and sodicity. Date in Table (2) show that the $\mathrm{pH}$ values of the studied ground water samples ranged from 7.07 to 8.07 , the normal recommended $\mathrm{pH}$ range for irrigation water from 6.5 to 8.4 according to (Ayres and westcot, 1985). The $\mathrm{ECw}$ values of the ground water samples ranged from $4.76 \mathrm{dS} / \mathrm{m}$ to 23.20 $\mathrm{dS} / \mathrm{m}$. All the collected ground water samples are very high saline according the classification of ground water samples (Ayres and westcot, 1985). Also date in Table (2) show that the concentration of soluble $\mathrm{Na}, \mathrm{Ca}+\mathrm{Mg}$ and $\mathrm{K}$ ions ranged from 36.66 to $187.88,6.08$ to 100.9 and 0.60 to 2.04 mmole $\mathrm{L}^{-1}$ with an average value of $74.23,31.18$ and 0.97 mmole $\mathrm{L}^{-1}$ respectively. Cations chemistry indicated that all the studied ground water samples have the descending arrange of $\mathrm{Na}>\mathrm{Ca}+\mathrm{Mg}>\mathrm{K}$. Anions chemistry indicated that $55.55 \%$ of the studied ground water samples have $\mathrm{Cl}^{-}>\mathrm{SO}_{4}{ }^{=}>\mathrm{HCO}_{3}>\mathrm{CO}_{3}$ while the remaining sample here $44.44 \mathrm{SO}_{4}>\mathrm{Cl}^{-}>\mathrm{HCO}_{3}>\mathrm{CO}_{3}$.

date in Table (3) show that SAR values ranged from 10.71 to 30.43 , according to (Todd,1980) six ground water samples $(4,3,13,16,15$ and 12) are good, nine are fair $(1,5,2,9,11,7,14,8,6$ and 17$)$ and two samples are poor (10 and 18). Also date in Table (3) show that the nitrate $\left(\mathrm{NO}_{3}\right)$ values of the studied ground water samples ranged from 0.77 to $347 \mathrm{mg} / \mathrm{l}$. According to FAO (1976) in guidelines are reported as nitrate in three categories, as follows:

Fayoum J. Agric. Res. \& Dev., Vol. 31, No.1, January, 2017 
IMPACT OF GROUND WATER SALINITY AND SODICITY.

Water class

No problem

Increasing

Sever problem

$\mathrm{NO}_{3} \mathrm{mg} / \mathrm{l}$

$<5$

$>30$

Ground water samples

\author{
14 and 15
}

$5,2,10,7,16,6,17$ and 15

$1,4,9,11,3,8,13$ and 18

Data presented in Table (3) show that percent sodium value of the studied ground water samples varied from 49.9 to $87.78 \%$. A maximum of $60 \%$ sodium in ground water is allowed for agricultural. It could be concluded from the classification of (Ragunath, 1987) that, 15 ground water samples are doubtful (83.3\%), one sample is permissible (5.5\%) and two samples are unsuitable (11.1\%).

Table (2): Some chemical analysis of the ground water table samples of the studied soil profiles of the three sample areas.

\begin{tabular}{|c|c|c|c|c|c|c|c|c|c|}
\hline \multirow{2}{*}{ Pr.No } & \multirow{2}{*}{$\begin{array}{l}\text { Water table } \\
\text { depth }(\mathbf{c m})\end{array}$} & \multirow{2}{*}{ EC dS/m } & \multicolumn{3}{|c|}{ Soluble cations ( mmole $\mathrm{L}^{-1}$ ) } & \multicolumn{4}{|c|}{ Soluble anions ( mmole $\mathbf{L}^{-1}$ ) } \\
\hline & & & $\mathrm{Mg}^{++}+\mathrm{Ca}^{++}$ & $\mathrm{Na}^{+}$ & $\mathbf{K}^{+}$ & $\mathrm{CO}^{=}$ & $\mathrm{HCO}_{3}^{-}$ & $\mathrm{Cl}^{-}$ & $\mathrm{SO}_{4}=$ \\
\hline 1 & 40 & 17.70 & 55.36 & 120.43 & 1.19 & - & 10.04 & 100.40 & 66.54 \\
\hline 2 & 60 & 8.00 & 20.16 & 59.09 & 0.74 & - & 4.43 & 42.97 & 32.59 \\
\hline 3 & 70 & 6.46 & 16.00 & 47.98 & 0.61 & - & 4.12 & 29.92 & 30.55 \\
\hline 4 & 60 & 7.64 & 21.76 & 53.92 & 0.71 & - & 3.96 & 40.25 & 32.18 \\
\hline 5 & 55 & 10.33 & 29.60 & 72.34 & 1.35 & - & 5.20 & 51.74 & 46.35 \\
\hline 6 & 80 & 7.15 & 16.64 & 53.94 & 0.91 & - & 6.96 & 30.09 & 34.44 \\
\hline 7 & 70 & 7.90 & 18.56 & 59.84 & 0.60 & - & 7.76 & 33.26 & 37.98 \\
\hline 8 & 75 & 12.13 & 60.76 & 59.07 & 1.45 & - & 21.19 & 52.87 & 47.22 \\
\hline 9 & 60 & 8.04 & 16.75 & 62.67 & 0.96 & - & 7.49 & 37.62 & 35.27 \\
\hline 10 & 60 & 15.35 & 48.01 & 104.43 & 1.04 & - & 8.71 & 87.06 & 57.71 \\
\hline 11 & 60 & 23.20 & 100.9 & 187.88 & 1.03 & - & 5.94 & 155.00 & 128.87 \\
\hline 12 & 120 & 9.83 & 21.76 & 75.61 & 0.92 & - & 6.71 & 42.43 & 49.15 \\
\hline 13 & 80 & 9.92 & 38.20 & 59.58 & 1.41 & - & 7.43 & 44.83 & 46.93 \\
\hline 14 & 70 & 4.98 & 6.08 & 43.01 & 0.70 & - & 4.36 & 21.67 & 23.76 \\
\hline 15 & 100 & 4.76 & 10.24 & 36.66 & 0.69 & - & 8.71 & 13.2 & 25.68 \\
\hline 16 & 80 & 7.25 & 19.04 & 52.75 & 0.70 & - & 8.32 & 35.37 & 28.8 \\
\hline 17 & 100 & 10.20 & 39.93 & 87.10 & 0.46 & - & 2.97 & 83.41 & 41.11 \\
\hline 18 & 80 & 12.38 & 21.6 & 100.01 & 2.04 & - & 10.69 & 61.88 & 51.08 \\
\hline
\end{tabular}

Fayoum J. Agric. Res. \& Dev., Vol. 31, No.1, January, 2017 
Hala Hussein R. et al.,

Table (3):Some chemical analysis of the ground water table samples of the studied soil profiles of the three sample areas.

\begin{tabular}{|c|c|c|c|c|c|}
\hline Pr.No & $\begin{array}{c}\text { Water table } \\
\text { depth(cm) }(\mathbf{c m})\end{array}$ & $\mathbf{p H}$ & $\mathbf{S A R}$ & $\mathbf{N O}_{\mathbf{3}}^{-} \mathbf{~ m g / L}$ & $\mathbf{N a}$ \% \\
\hline $\mathbf{1}$ & 40 & 7.48 & 22.89 & 80.50 & 68.04 \\
\hline $\mathbf{2}$ & 60 & 7.75 & 18.61 & 29.00 & 73.87 \\
\hline $\mathbf{3}$ & 70 & 7.37 & 16.96 & 126.00 & 74.28 \\
\hline $\mathbf{4}$ & 60 & 7.63 & 16.34 & 90.00 & 70.58 \\
\hline $\mathbf{5}$ & 55 & 7.54 & 18.80 & 9.63 & 70.03 \\
\hline $\mathbf{6}$ & 80 & 7.54 & 18.70 & 15.88 & 75.45 \\
\hline $\mathbf{7}$ & 70 & 7.54 & 19.64 & 7.92 & 75.74 \\
\hline $\mathbf{8}$ & 75 & 7.07 & 10.71 & 13.60 & 48.70 \\
\hline $\mathbf{9}$ & 60 & 7.71 & 21.68 & 58.46 & 77.96 \\
\hline $\mathbf{1 0}$ & 60 & 7.55 & 21.31 & 46.50 & 68.04 \\
\hline $\mathbf{1 1}$ & 60 & 7.45 & 26.45 & 5.47 & 64.82 \\
\hline $\mathbf{1 2}$ & 120 & 7.74 & 22.92 & 135.50 & 76.92 \\
\hline $\mathbf{1 3}$ & 80 & 7.58 & 13.63 & 347.00 & 60.06 \\
\hline $\mathbf{1 4}$ & 70 & 8.07 & 24.66 & 2.83 & 86.38 \\
\hline $\mathbf{1 5}$ & 100 & 7.46 & 16.20 & 0.77 & 77.03 \\
\hline $\mathbf{1 6}$ & 80 & 7.41 & 17.09 & 7.52 & 72.76 \\
\hline $\mathbf{1 7}$ & 100 & 7.45 & 19.49 & 24.88 & 68.31 \\
\hline $\mathbf{1 8}$ & 80 & 7.79 & 30.43 & 149.00 & 80.88 \\
\hline
\end{tabular}

\section{Soil chemical properties}

Data in Table (4) show that the $\mathrm{pH}$ values of the studied soil profiles are in the alkali side and ranged from 7.08 to 8.29 indicating the effects of prevailing the alkali ions in soil solution and their considerable contents of calcium carbonate.

Soil salinity is extremely important during germination and emergence of seedling. Failure in germination and emergence leads to poor stand and significant reduction in yield (Maas and Hoffman, 1977).

The obtained data of the electrical conductivity (ECe) which were determined in the saturated soil paste extract. Table (4) showed that the electrical conductivity values of the studied soil profiles ranged from 6.28 to $23.14 \mathrm{dS} / \mathrm{m}$.

Fayoum J. Agric. Res. \& Dev., Vol. 31, No.1, January, 2017 
IMPACT OF GROUND WATER SALINITY AND SODICITY............ 130 Table(4):Chemical analysis of soil paste extract for the studied soil profiles sample area.

\begin{tabular}{|c|c|c|c|c|c|c|c|c|c|c|c|}
\hline \multirow{2}{*}{ Pr. No } & \multirow{2}{*}{$\begin{array}{l}\text { Depth } \\
\text { (cm) }\end{array}$} & \multirow{2}{*}{ pH } & \multirow{2}{*}{ ECe ds/m } & \multicolumn{4}{|c|}{$\begin{array}{c}\left.\text { Soluble cations ( mmole } \mathbf{L}^{-1}\right) \\
\left(\text { mmole } \mathbf{L}^{-1}\right)\end{array}$} & \multicolumn{4}{|c|}{$\begin{array}{c}\text { Soluble anions }\left(\text { mmole } \mathbf{L}^{-1}\right) \\
\left(\text { mmole } \mathbf{L}^{-1}\right)\end{array}$} \\
\hline & & & & $\mathrm{Ca}^{++}$ & $\mathrm{Mg}^{++}$ & $\mathrm{Na}^{+}$ & $\mathbf{K}^{+}$ & $\mathrm{CO}_{3}^{-}$ & $\mathrm{HCO}_{3}^{-}$ & $\mathrm{Cl}^{-}$ & $\mathrm{SO}_{4}=$ \\
\hline \multirow[t]{2}{*}{1} & $\begin{array}{l}0-20 \\
0-20 \\
\end{array}$ & 8.29 & $\begin{array}{l}20.50 \\
20.50 \\
\end{array}$ & 65.05 & 30.86 & 108.01 & 1.06 & - & 20.91 & 96.94 & 87.13 \\
\hline & $20-40$ & 8.01 & 18.10 & 69.37 & 31.30 & 78.72 & 1.58 & - & 15.60 & 100.65 & 64.72 \\
\hline \multirow{2}{*}{2} & $0-30$ & 7.79 & 15.45 & 30.36 & 20.79 & 101.49 & 1.84 & - & 14.74 & 68.96 & 70.78 \\
\hline & $30-60$ & 7.79 & 14.06 & 33.44 & 24.79 & 80.69 & 1.66 & - & 13.21 & 49.87 & 77.50 \\
\hline \multirow[b]{2}{*}{3} & $0-30$ & 7.78 & 12.14 & 36.55 & 32.74 & 50.12 & 1.97 & - & 45.85 & 68.78 & $\begin{array}{l}7111 \\
6.75 \\
\end{array}$ \\
\hline & $30-70$ & 7.87 & 12.24 & 63.14 & 13.67 & 43.92 & 1.65 & - & 28.89 & 71.18 & 22.31 \\
\hline \multirow[b]{2}{*}{4} & $0-30$ & 7.87 & 15.07 & 32.05 & 19.26 & 96.88 & 1.48 & - & 18.28 & 73.28 & 58.11 \\
\hline & $30-60$ & 7.87 & 14.41 & 21.43 & 8.12 & 113.18 & 1.35 & - & 14.28 & 117.29 & 12.51 \\
\hline \multirow{2}{*}{5} & $0-30$ & 7.84 & 23.14 & 24.30 & 18.9 & 242.40 & 1.90 & - & 7.50 & 221.50 & 58.50 \\
\hline & $30-55$ & 7.54 & 12.03 & 22.56 & 14.33 & 81.85 & 1.55 & - & 4.02 & 79.83 & 36.44 \\
\hline \multirow{2}{*}{6} & $0-40$ & 8.23 & 12.92 & 33.69 & 8.16 & 46.55 & 0.78 & - & 1.24 & 58.03 & 29.91 \\
\hline & $40-80$ & 8.25 & 9.80 & 39.70 & 6.15 & 51.63 & 0.51 & - & 10.06 & 46.34 & 41.59 \\
\hline \multirow{2}{*}{7} & $0-30$ & 7.65 & 17.43 & 25.95 & 17.25 & 129.19 & 1.89 & - & 8.04 & 40.65 & 125.509 \\
\hline & $30-70$ & 7.43 & 16.82 & 29.67 & 30.06 & 107.16 & 1.29 & - & 15.02 & 92.24 & 60.92 \\
\hline \multirow{3}{*}{8} & $0-20$ & 7.35 & 17.46 & 51.89 & 21.11 & 99.70 & 1.78 & - & 10.35 & 135.61 & 28.52 \\
\hline & $20-45$ & 7.50 & 13.85 & 37.24 & 13.46 & 86.11 & 1.63 & - & 6.16 & 106.60 & 25.58 \\
\hline & $45-75$ & 7.37 & 10.83 & 27.78 & 12.54 & 98.21 & 1.85 & - & 8.02 & 115.53 & 16.83 \\
\hline \multirow{2}{*}{9} & $0-30$ & 7.98 & 18.35 & 27.54 & 27.54 & 126.57 & 1.84 & - & 20.01 & 150.19 & 13.29 \\
\hline & $30-60$ & 7.88 & 14.36 & 16.24 & 16.24 & 110.24 & 0.88 & - & 12.56 & 75.76 & 55.28 \\
\hline \multirow{2}{*}{10} & $0-30$ & 8.24 & 27.40 & 81.60 & 49.30 & 199.80 & 1.80 & - & 20.30 & 241.70 & 70.50 \\
\hline & $30-60$ & 7.82 & 17.10 & 37.12 & 8.72 & 123.88 & 1.26 & - & 15.04 & 107.54 & 48.40 \\
\hline \multirow{2}{*}{11} & $0-30$ & 8.09 & 8.72 & 25.36 & 7.44 & 53.76 & 0.63 & - & 8.96 & 41.84 & 36.39 \\
\hline & $30-60$ & 7.99 & 7.94 & 13.94 & 8.65 & 55.91 & 0.88 & - & 13.94 & 17.45 & 47.99 \\
\hline \multirow{4}{*}{12} & $0-30$ & 7.50 & 7.30 & 18.12 & 12.45 & 41.51 & 0.89 & - & 7.66 & 32.12 & 33.19 \\
\hline & $30-70$ & 7.43 & 7.22 & 22.09 & 14.58 & 34.54 & 0.98 & - & 9.38 & 36.24 & 26.57 \\
\hline & $70-100$ & 7.65 & 8.41 & 24.62 & 14.16 & 44.44 & 0.86 & - & 13.24 & 45.85 & 24.99 \\
\hline & $100-120$ & 7.68 & 10.09 & 27.79 & 11.66 & 60.94 & 0.48 & - & 12.81 & 72.15 & 15.85 \\
\hline \multirow{2}{*}{13} & $0-40$ & 7.22 & 15.03 & 50.83 & 30.79 & 67.55 & 1.10 & - & 16.85 & 48.59 & 84.83 \\
\hline & $40-80$ & 7.28 & 10.00 & 21.25 & 18.13 & 59.63 & 0.98 & - & 8.22 & 56.85 & 34.92 \\
\hline \multirow{2}{*}{14} & $0-20$ & 7.68 & 8.15 & 20.37 & 6.98 & 53.00 & 0.82 & - & 19.69 & 41.85 & 19.63 \\
\hline & $20-70$ & 7.93 & 6.28 & 15.87 & 5.13 & 40.49 & 1.32 & - & 14.31 & 30.41 & 18.07 \\
\hline \multirow{2}{*}{15} & $0-40$ & 7.33 & 8.11 & 21.08 & 9.78 & 49.11 & 1.00 & - & 13.61 & 23.64 & 43.72 \\
\hline & $40-100$ & 7.35 & 6.81 & 29.66 & 5.89 & 31.69 & 0.85 & - & 10.78 & 8.76 & 48.55 \\
\hline \multirow{2}{*}{16} & $0-30$ & 7.37 & 16.77 & 35.50 & 22.68 & 107.59 & 1.90 & - & 14.78 & 69.06 & 83.83 \\
\hline & $30-80$ & 7.32 & 14.96 & 41.57 & 19.85 & 101.80 & 1.40 & - & 13.48 & 91.99 & 59.15 \\
\hline \multirow{2}{*}{17} & $0-30$ & 7.85 & 9.82 & 25.30 & 16.84 & 54.58 & 1.30 & - & 2.01 & 52.96 & 43.05 \\
\hline & $30-90$ & 7.85 & 9.81 & 27.87 & 16.47 & 52.70 & 0.96 & - & 4.03 & 43.41 & 50.56 \\
\hline & $0-40$ & 7.17 & 18.44 & 40.98 & 31.77 & 110.23 & 1.36 & - & 10.63 & 102.905 & 70.76 \\
\hline & $40-80$ & 7.08 & 12.22 & 29.32 & 17.41 & 74.39 & 1.04 & - & 10.60 & 63.68 & 47.88 \\
\hline
\end{tabular}

Fayoum J. Agric. Res. \& Dev., Vol. 31, No.1, January, 2017 
Table (4) shows also the obtained soluble cations and anions values of the investigated soil profiles. It is noteworthy to indicate that the dominate soluble cations in all studied soil profiles are sodium followed by calcium and / or magnesium while potassium exhibits extremely low contents. Also, the dominant soluble anions in the investigated soil profiles were chloride followed by sulphate while soluble bicarbonate was low and rather constant compared to the other anions. Thus, it can be noticed that the dominant salt in the studied soil profiles was $\mathrm{NaCl}$ followed by $\mathrm{Na}_{2} \mathrm{SO}_{4}, \mathrm{MgCl}_{2}, \mathrm{MgSO}_{4}$ and $\mathrm{CaCl}_{2}$. However, the concentration of soluble cations and/or anions may differ when water table got deeper, such findings are parallel with those stated by (Salassie et al.,1992).

Data in Table (5) illustrates the values of CEC in Cmole/ $\mathrm{kg}$ soil of the first sample area. Values of CEC varied between 4.05 to $45.90 \mathrm{Cmole} / \mathrm{kg}$ soil. It is noteworthy to mention that, CEC values of the surface layers are higher than that of subsurface layers in most of the investigated soil profiles. Such findings may be attributed to the high content of organic matter in the surface layers when compared with the subsurface layers, which may rendered to cultivation practices. 
IMPACT OF GROUND WATER SALINITY AND SODICITY .......... 132

Table(5):Organic matter, total $\mathrm{CaCO}_{3}$, exchangeable $\mathrm{Na}^{+}$, cation exchange capacity and exchangeable sodium percentage of the studied soil profiles of sample area.

\begin{tabular}{|c|c|c|c|c|c|c|}
\hline Pr. No & Depth $(\mathrm{cm})$ & $\begin{array}{c}\text { Organic } \\
\text { matter }(\%)\end{array}$ & $\mathrm{Ca} \mathrm{CO}_{3}(\%)$ & $\begin{array}{c}\text { Exchangeable } \mathrm{Na}^{+} \\
\text {Cmole/kg soil }\end{array}$ & $\begin{array}{c}\text { CEC Cmole } \\
\text { /kg soil }\end{array}$ & $\operatorname{ESP}(\%)$ \\
\hline \multirow{2}{*}{1} & $0-20$ & 0.54 & 5.50 & 2.28 & 13.05 & 17.47 \\
\hline & $20-40$ & 0.49 & 4.60 & 0.93 & 4.05 & 22.96 \\
\hline \multirow{2}{*}{2} & $0-30$ & 0.94 & 4.30 & 1.96 & 31.35 & 6.25 \\
\hline & $30-60$ & 0.77 & 3.40 & 2.20 & 14.32 & 15.36 \\
\hline \multirow{2}{*}{3} & $0-30$ & 0.92 & 3.00 & 7.10 & 30.07 & 23.61 \\
\hline & $30-70$ & 0.78 & 2.50 & 1.20 & 14.85 & 8.08 \\
\hline \multirow{2}{*}{4} & $0-30$ & 0.98 & 7.10 & 4.05 & 45.90 & 8.82 \\
\hline & $30-60$ & 0.80 & 6.70 & 2.13 & 43.80 & 4.86 \\
\hline \multirow{2}{*}{5} & $0-30$ & 0.81 & 6.00 & 8.36 & 45.52 & 18.35 \\
\hline & $30-55$ & 0.46 & 5.60 & 3.12 & 20.70 & 15.07 \\
\hline \multirow{2}{*}{6} & $0-40$ & 0.40 & 3.80 & 1.67 & 29.85 & 5.59 \\
\hline & $40-80$ & 0.37 & 3.50 & 2.89 & 14.17 & 20.39 \\
\hline \multirow{2}{*}{7} & $0-30$ & 0.77 & 6.60 & 7.10 & 38.32 & 18.52 \\
\hline & $30-70$ & 0.52 & 4.10 & 1.20 & 7.27 & 16.51 \\
\hline \multirow{3}{*}{8} & $0-20$ & 0.77 & 3.90 & 1660 & 35.85 & 46.30 \\
\hline & $20-45$ & 0.56 & 3.00 & 3.72 & 13.35 & 27.86 \\
\hline & $45-75$ & 0.44 & 4.50 & 3.60 & 12.90 & 27.90 \\
\hline \multirow{2}{*}{9} & $0-30$ & 0.78 & 8.60 & 8.36 & 39.22 & 21.31 \\
\hline & $30-60$ & 0.52 & 6.20 & 3.12 & 15.57 & 20.03 \\
\hline \multirow{2}{*}{10} & $0-30$ & 0.98 & 4.00 & 3.05 & 14.40 & 21.18 \\
\hline & $30-60$ & 0.86 & 3.00 & 3.90 & 9.65 & 40.41 \\
\hline \multirow{2}{*}{11} & $0-30$ & 0.77 & 12.50 & 2.42 & 24.67 & 9.80 \\
\hline & $30-60$ & 0.68 & 7.50 & 3.08 & 13.57 & 22.69 \\
\hline \multirow{4}{*}{12} & $0-30$ & 0.41 & 5.70 & 0.28 & 13.72 & 2.04 \\
\hline & $30-70$ & 0.36 & 5.30 & 0.18 & 4.27 & 4.21 \\
\hline & $70-100$ & 0.34 & 6.00 & 0.19 & 4.20 & 4.52 \\
\hline & $100-120$ & 0.32 & 4.80 & 0.29 & 8.32 & 3.48 \\
\hline \multirow{2}{*}{13} & $0-40$ & 0.92 & 5.00 & 1.65 & 14.70 & 11.22 \\
\hline & $40-80$ & 0.57 & 5.00 & 2.35 & 15.35 & 15.30 \\
\hline \multirow{2}{*}{14} & $0-20$ & 0.80 & 3.60 & 3.05 & 14.02 & 21.75 \\
\hline & $20-70$ & 0.61 & 3.30 & 1.22 & 4.87 & 25.05 \\
\hline \multirow{2}{*}{15} & $0-40$ & 0.45 & 4.90 & 0.77 & 35.10 & 9.61 \\
\hline & $40-100$ & 0.40 & 3.20 & 1.15 & 4.80 & 23.95 \\
\hline \multirow{2}{*}{16} & $0-30$ & 0.67 & 6.00 & 1.31 & 34.27 & 3.82 \\
\hline & $30-80$ & 0.49 & 4.00 & 2.90 & 14.10 & 20.56 \\
\hline \multirow{2}{*}{17} & $0-30$ & 0.51 & 1.20 & 2.20 & 21.22 & 10.36 \\
\hline & $30-90$ & 0.46 & 1.90 & 1.96 & 18.15 & 10.79 \\
\hline \multirow{2}{*}{18} & $0-40$ & 0.82 & 7.00 & 2.13 & 41.55 & 5.12 \\
\hline & $40-80$ & 0.61 & 6.00 & 4.05 & 14.70 & 27.55 \\
\hline
\end{tabular}

Fayoum J. Agric. Res. \& Dev., Vol. 31, No.1, January, 2017 
Hala Hussein R. et al.,

While the values of ESP ranged from 2.04 to $46.30 \%$ reflecting the nature of salinity and cations distributions. It could be concluded that $68.75 \%$ of the studied soil profiles are sodic soils.

\section{Statistical analysis}

The descriptive statistical parameters for studied ground water characteristics and soil variables are shown in Table (6).

Table (6):Simple correlation between ground water characteristics and some soil properties.

\begin{tabular}{|c|c|c|c|c|c|}
\hline \multirow{2}{*}{$\begin{array}{l}\text { Characteristics of } \\
\text { ground water }\end{array}$} & \multicolumn{5}{|c|}{ Characteristics of soil samples } \\
\hline & layer & ECe & ESP & Clay & $\mathbf{P H}$ \\
\hline \multirow[t]{2}{*}{ G.W-depth } & Surface & $-0.529^{*}$ & $-0.477^{*}$ & -0.150 & -0.587 \\
\hline & Sub & $-0.514^{*}$ & $-0.521^{*}$ & -0.220 & -0.458 \\
\hline \multirow[t]{2}{*}{ G.W-EC } & Surface & $0.778^{* * *}$ & 0.376 & 0.344 & 0.400 \\
\hline & Sub & $0.872^{* *}$ & 0.442 & -0.262 & 0.240 \\
\hline \multirow[t]{2}{*}{ G.W-SAR } & Surface & $0.479^{*}$ & $0.732^{* * *}$ & 0.043 & 0.234 \\
\hline & Sub & $0.487^{*}$ & $0.795^{*}$ & -0.172 & 0.116 \\
\hline \multirow[t]{2}{*}{ G.W-Na ${ }^{+}$} & Surface & $0.793^{* *}$ & $0.543^{*}$ & -0.280 & 0.434 \\
\hline & Sub & $0.861^{* *}$ & $0.495^{*}$ & -0.232 & 0.260 \\
\hline \multirow[t]{2}{*}{ G.W-pH } & Surface & $\begin{array}{l}-0.108 \\
\end{array}$ & 0.323 & 0.142 & 0.034 \\
\hline & Sub & -0.112 & 0.277 & 0.136 & 0.049 \\
\hline
\end{tabular}

**. Correlation is significant at the 0.01 level

* Correlation is significant at the 0.05 level

From data in Table (6), negative significant correlations $\left(-0.529^{*}\right)$ and $(-0.514 *)$ were recorded between depth of ground water and soil salinity values $(\mathrm{ECe})$ in the surface and subsurface layers respectively.

Also, negative significant correlations $\left(-0.477^{*}\right)$ and $\left(-0.521^{*}\right)$ between depth of ground water and exchangeable sodium percent\% (ESP) in the surface and subsurface layers respectively.

While negative significant correlations $\left(-0.587^{*}\right)$ between depth of ground water and $\mathrm{pH}$ in soil for surface layers and no significant correlations in subsurface layers with correlation coefficient $(-0.458)$. The general trend line showed that soil salinity increased with an increased in water salinity. This reveals to contribution of shallow ground water in the salinization process in the profiles. Which the increased of the ground water depth to be lower in soil salinity. The aforementioned conclusion is confirmed by the high significant positive correlations with correlation coefficient $\left(0.778^{* *}\right)$ and $\left(0.872^{* * *}\right)$ for surface and subsurface layer respectively. Significant positive correlations with correlation coefficient $\left(0.479^{*}\right)$ and $\left(0.487^{*}\right)$ between ground water salinity and sodium adsorption ratio (SAR) in the surface and subsurface layers respectively.

Fayoum J. Agric. Res. \& Dev., Vol. 31, No.1, January, 2017 
Significant high positive correlation between sodium adsorption ratio (SAR) in ground water and Exchangeable sodium percent\% (ESP) in soil with correlation coefficient of $\left(0.732^{* *}\right)$ and $\left(0.795^{* *}\right)$ for surface and subsurface layers respectively.

While significant high positive correlation between sodium cation in ground water and soil salinity with correlation coefficient $\left(0.793^{* *}\right)$ and $\left(0.861^{* * *}\right)$ for surface and subsurface layer respectively. While significant positive correlation between sodium cation in ground water and exchangeable sodium percent\% (ESP) in soil with correlation coefficient of $\left(0.543^{*}\right)$ and $\left(0.495^{*}\right)$ for surface and subsurface layer respectively.

Non-significant correlation between soil $\mathrm{pH}$ and ground water $\mathrm{pH}$ with correlation coefficient (0.034 and 0.049) for surface and subsurface layers respectively.

\section{REFERENCES}

Ali, R.; Elliott, J.; Ayers, E. and Stevens, E. W., (2000). Soil salinity modeling over water table. J. Irri. Drain Eng. 126 (4): 234-242.

APHA- AWWA- WEF. (2005). Standerd Method For The Examination Of Water and West Water .21 $1^{\text {st }}$ Edition Method 4500-H+, PP(4-90)to(494).

Ashraf, M.; Rahmatullh, T.; Maqsood, T. and Tahir, M.A, (2006). Contribution of shallow water table to salinity/sodicity development under fallow and cropped conditions. Pak. J. Agri. Sci., 43 (1-2).

Ayers, R.S. and Westcot, D.W.(1985). Water quality for agriculture. FAO Irrigation and Drainage Paper No. 29. Rome, Italy: 174.

Elrick, D.E.; Mermoud, A. and Monnier, T., (1994). Analysis of solute accumulation during steady-state evaporation in an initially contaminated soil. J. of Hydrology, 155: 27-38.

Fan, Y.; Li, H. and Miguez-Macho, G. ( 2013). Global Patterns of Ground water Table Depth. Science. 339 (6122): 940-943.

FAO (1976). Prognosis of salinity and alkalinity. Soils Bulletin 31, FAO, Rome.

Hassan, M. M.; El-Masry, T. A, and abou-arab, A. A. (1999). Effect of soil salinity on growth, yield and elemental concentration in tomato. Egypt. J., Hort. Sci., 26:187-198.

Maas, E.V. and Hoffman, G.S. (1977). Crop salt tolerance current assessment. J. of irrigation and drainage division ASCE, 103: 115134.

Klute, A. (1986). Methods of Soil Analysis -Part- 1, Physical and Mineralogical Methods. $2^{\text {nd }}($ Ed.). American Society of Agronomy, Madison, Wisconsin, U.S.A.

Fayoum J. Agric. Res. \& Dev., Vol. 31, No.1, January, 2017 
Hala Hussein R. et al.,

Page, A. L. ; Miller, R. H. and Keeney, D. R. (1982). Methods of Soil Analysis. Part 2. Chemical and Microbiological Properties. $2^{\text {nd }}$ (Ed.). Amer. Soc. of Agronomy. Madison, Wisconsin, USA.

Regunath, H.M. (1987). Ground water. Wiley Eastern L td, New Delhi, P 563.

Rhoads, J.D.; Kandiah, A. and Mashali, A.M. (1992). The use of saline waters for crop production. FAO, irrigation and drainage, P. 48.

Saeed, J.;Saeed, B.N.; Hadi, M. and Abd, A. N., (2011). Effect of shallow saline - groundwater depth on evaporation rate. World Rural Observation, 3 (4): 65-70.

Selassie, T.D.; Jurinak, J. J. and Dudley, L.M. (1992). Saline and sodic saline soil reclamation. First order kinetic model of capillary up flow from water table under maize soil, in irrigated soils. Austrian J. Soil Res., 31:119 - 130. Soil Sci., 1-7.

Todd, D. (1980). Ground water hydrology $\left(2^{\text {nd }}\right.$ ed.): Wiley. New York.

Wicox, L. V., (1995). Classification and Use of Irrigation Waters, US Department of Agriculture, Washington DC, p19.

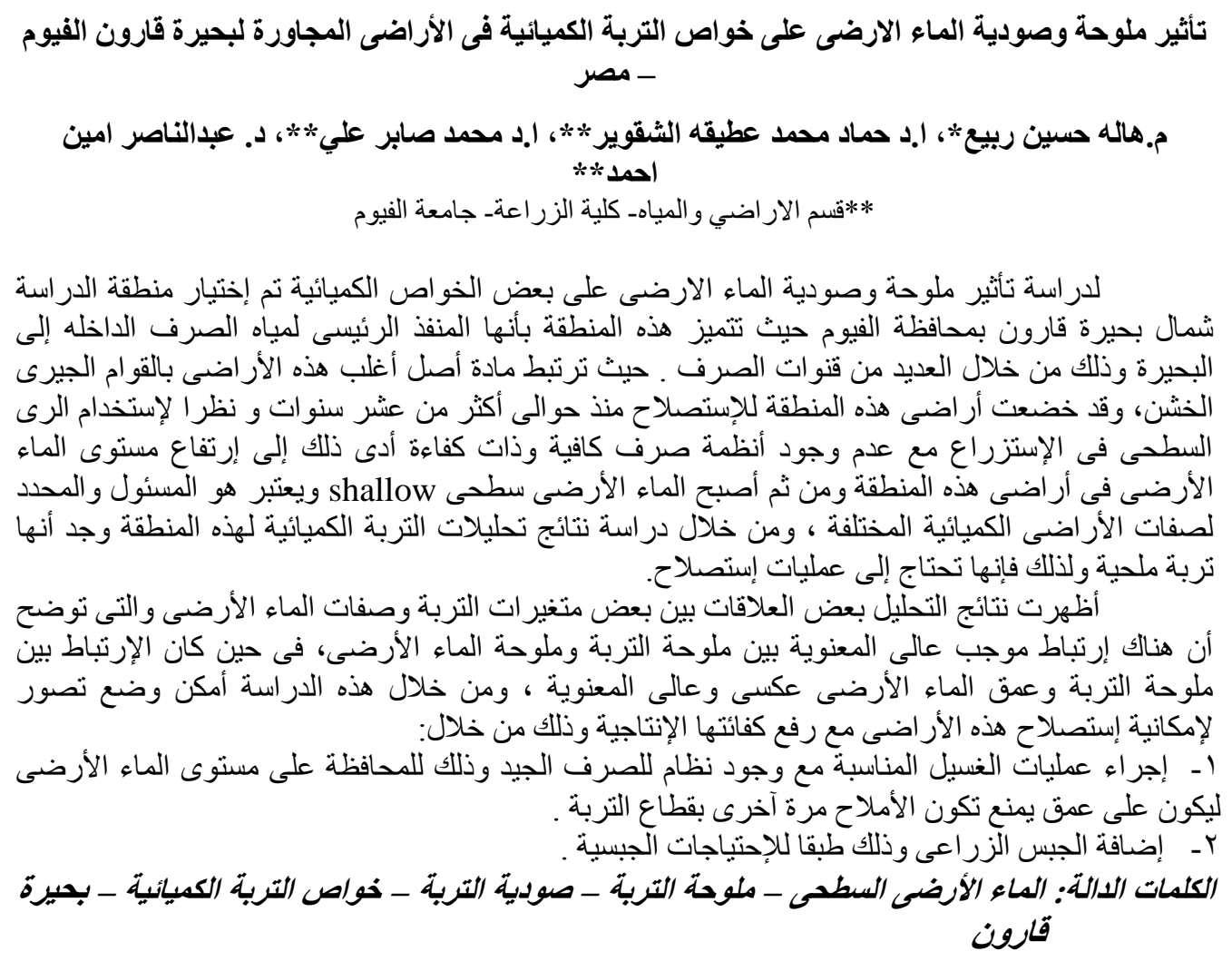

Fayoum J. Agric. Res. \& Dev., Vol. 31, No.1, January, 2017 